Available online on 15.02 .2020 at http://jddtonline.info
Open Access to Pharmaceutical and Medical Research
unrestricted non-commercial use, provided the original work is properly cited

Open Access

Letter to Editor

\title{
Legalize cannabis in Nepal to improve Health and Economy
}

\author{
Dirgha Raj Joshi \\ PhD Scholar, Yonsei University, College of Pharmacy, Republic of Korea
}

Article Info: Received 22 Dec 2019; Review Completed 22 Jan 2020; Accepted 30 Jan 2020; Available online 15 Feb 2020

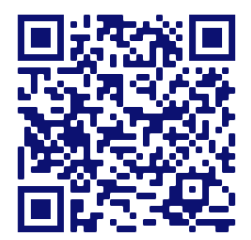

Cite this article as:

Joshi DR, Legalize cannabis in Nepal to improve Health and Economy, Journal of Drug Delivery and Therapeutics. 2020; 10(1-s):185-186 http://dx.doi.org/10.22270/jddt.v10i1-s.3872

*Address for Correspondence:

Dirgha Raj Joshi, PhD Scholar, Yonsei University, College of Pharmacy, Republic of Korea.

Email: djmeropaila121@gmail.com, djmeropaila121@yonsei.ac.kr

Dear Editor,

The legalization of cannabis is increasing these days in several western countries including the USA for the purpose of medicinal as well as recreational. Many derivative drugs from cannabis are in the market. A large population is involved in cannabis-related agriculture, processing, distribution, recreational consumer, traditional healers, Ayurveda practices and many either in a legal or an illegal way.

With growing legalization in many countries it is also affecting the economy of the country and in the near future, it could be a major option for economic growth. Having enormous potencies, verified scientific documents and a beginner of cannabis practice is an Indian subcontinent but we are lagging on proper utilization of this potential plant. The value of cannabis is reported in our Vedic scriptures and its utilization are ethno-medicinally verified from thousands year ago. So the human and cannabis relation is long even this plant is given to animals to treat diarrhea and other complications.

But due to political instability, with influence of Western countries Nepal band the production, distribution and use of cannabis and related products from few decades. Still we are not in way of legalization, we are the pioneer to show the potency of cannabis and even clearly mentioned it's value in our Vedic scripture but Nepal cannot properly address it to make legalize, build economy based on it, focus on export and improve the health and economy of people.

Almost of the scientific research on this plants are performed in western countries and we are only catching people, putting them in jail who ever involved with its production, distribution and use. Police are destroying cannabis from the farmers land and putting them in jail, how low we will go this way?, isn't it a time to legalize and make public healthy and wealthy?

We all know it can form a habit, overuse may harm society, so it should be strictly controlled and even farming and all other processes should be done in a controlled way but it should be legalized as soon as possible.

A large amount of people's money in south Asia is spending to buy expensive medicine which is derivatives from cannabis to treat Epilepsy, Parkinson's, other mental illness and many more. Actually, the government is doing crime on peoples because forcing to buy medicine from the western world which is discovered from cannabis but not allowing peoples to involve in cannabis in Nepal. Even our local practitioners make various formulation based on it to treat many diseases, these days getting cannabis becomes difficult, and more scare from police administration makes unhealthy; as we know our large population depends on traditional healers.

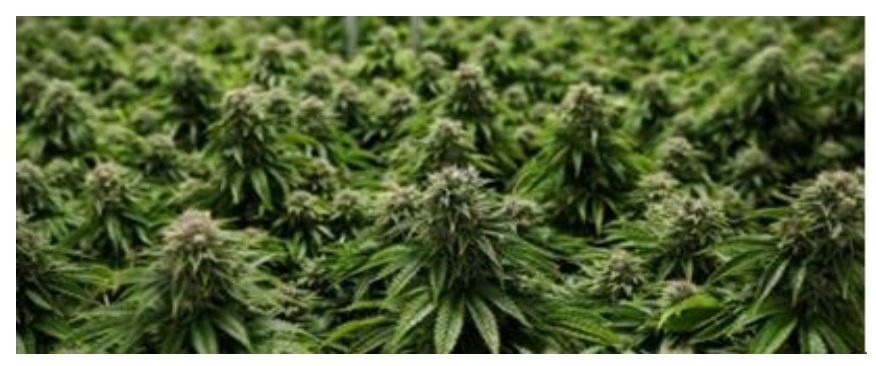

Figure 1: Cannabis Plant 
From the barks of cannabis, we can make jute, seeds for pickles and many other purposes, and the secondary metabolites for treating various diseases. Cannabinoids are major secondary metabolites in cannabis plants and found effective in treating diabetes, depression, pain, fever and many other diseases. The psychoactive Cannabidiol (CBD), Tetrahydrocannabinol (THC) and other non-psychoactive constituents are also widely researched.

Behind having enormous potencies a careful strategy should be established before legalizing it so that it will not go to the hands of bad peoples to misuse it. A research institute, well- trained staff, testing laboratories, public awareness, and proper production, process and distribution channel should be set up.

Considering its wide scope a proper collaboration with India, China, Bangladesh, and other countries is needed to export, grow its business in these areas and overall for the better health of Indian subcontinents and the western world. Let's be again beginner to build a new dimension of cannabis.

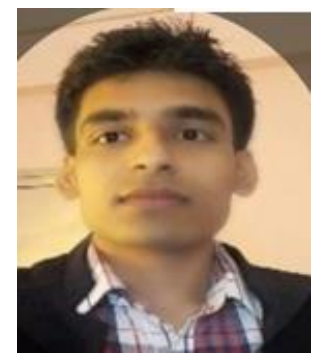

About the Author:

\section{Dirgha Raj Joshi}

PhD Scholar, Yonsei University, College of Pharmacy, Republic of Korea.

Past: National Secretary at Pragyik Vidyarthi Parishad Nepal, Secretary at Society of Nepalese Students in Korea,

President at Crimson Association of Pharma students.

Email: djmeropaila121@yonsei.ac.kr

This is an open access article distributed under the terms of the Creative Commons Attribution-NonCommercial-ShareAlike 4.0 License, which allows others to remix, tweak, and build upon the work non-commercially, as long as the author is credited and the new creations are licensed under the identical terms. 